\title{
ANALISA KANDUNGAN LOGAM BERAT DAN ION ASAM (NITRAT DAN SULFAT) DALAM AIR ISI ULANG DI PEKANBARU
}

\author{
Lazulva, Richa Elni Windri dan Melda
}

\author{
Jurusan Pendidikan Kimia, Fakultas Tarbiyah dan Keguruan, Universitas Islam Negeri Sultan Syarif Kasim, Riau \\ 28293, Indonesia. \\ E-mail: lazoelva_l154@yahoo.com
}

\begin{abstract}
ABSTRAK
Analisa kandungan logam berat pada air baku dan air isi ulang di daerah Panam, Tangkerang, dan Gobah, Pekanbaru telah dilakukan. Logam berat yang dianalisa adalah $\mathrm{Fe}$ dan $\mathrm{Cu}$. Hasilnya menunjukkan bahwa kadar logam berat pada air baku dan air isi ulang realtif rendah dan masih sesuai dengan nilai ambang batas (NAB) syarat kualitas air minum yang ditetapkan dalam Peraturan Menteri Kesehatan RI. Selain logam berat juga diukur parameter fisika dan kimia seperti suhu, warna dan $\mathrm{pH}$, nitrat dan sulfat. Hasilnya menunjukkan parameter fisika masih sesuai dengan NAB yang ditetapkan dalam Peraturan Menteri Kesehatan. Untuk parameter kimia yaitu nitrat dan sulfat masih sesuai dengan $\mathrm{NAB}$, namun untuk $\mathrm{pH}$ masih belum memenuhi syarat air minum karena $\mathrm{pH}$ air baku dan isi ulangnya dibawah standar yang telah ditentukan.
\end{abstract}

Kata kunci: logam, ambang, kesehatan, parameter

\section{PENDAHULUAN}

Air adalah sangat penting bagi kehidupan manusia. Di dalam tubuh manusia itu sendiri sebagian besar terdiri dari air. Tubuh orang dewasa, sekitar $55-65 \%$ berat badan terdiri dari air, untuk anak-anak sekitar $65 \%$, dan untuk bayi sekitar $80 \%$. Kehilangan air untuk $15 \%$ dari berat badan dapat mengakibatkan kematian. Bagi manusia, kebutuhan akan air mutlak, karena sebenarnya zat pembentuk tubuh manusia sebagian besar terdiri dari air. Oleh karena itu kehidupan ini tidak mungkin dapat dipertahankan tanpa air [1-4].

Mengkonsumsi air minum dari depot isi ulang kini jadi pilihan baru. Selain praktis karena tidak perlu dimasak lagi, mudah mendapatkannya dan harganya yang relatif terjangkau. Air yang tidak memenuhi persyaratan kesehatan dapat menyebabkan gangguan bagi yang mengkonsumsinya [5]. Adapun persyaratan yang layak minum adalah air yang memenuhi persyaratan bakteriologis, kimiawi, tidak mengandung logam berat yang diakibatkan oleh limbah, radioaktif dan fisika. Jenis logam berat yang tergolong memiliki toksisitas tinggi antara lain $\mathrm{Hg}, \mathrm{Cd}, \mathrm{Cu}, \mathrm{Ag}, \mathrm{Ni}, \mathrm{Pb} \mathrm{As}, \mathrm{Cr}, \mathrm{Sn}, \mathrm{Zn}$ dan Mn. [6-8]. Air minum adalah air yang melalui proses pengolahan atau tanpa proses pengolahan yang memenuhi syarat kesehatan dan langsung dapat diminum. Berdasarkan pengertian tersebut, maka kualitas air minum harus memenuhi standar persyaratan yang diatur dalam Keputusan Menteri Kesehatan Republik Indonesia No. 492/MENKES/PER/IV/2010 tentang syaratsyarat dan pengawasan kualitas air. Penelitian ini bertujuan untuk mengetahui kadar beberapa logam berat dan parameter fisika serta kimia dari air baku dan air isi ulang yang terdapat di kota Pekanbaru.

\section{METODOLOGI PENELITIAN}

Bahan. Bahan yang digunakan adalah $\mathrm{FeSO}_{4}$, kristal $\mathrm{KNO}_{3}, \mathrm{H}_{2} \mathrm{SO}_{4}$ p.a. CuSO $4.5 \mathrm{H}_{2} \mathrm{O}, \mathrm{HNO}_{3}$ p.a, $\mathrm{BaCl}_{2}, \mathrm{Na}_{2} \mathrm{SO}_{4}$ dan akuades.

Alat. Alat yang digunakan adalah water sampler, peralatan AAS tipe AA 6200, Spektrofotometer UV-Vis-1601 Shimadzu, $p H$ meter, termometer, oven, timbangan analitik, labu ukur $100 \mathrm{~mL}$, Labu ukur $500 \mathrm{~mL}$, Erlenmeyer $250 \mathrm{~mL}$, kertas Whatman No.40 dan Aluminium Foil

\section{Perlakuan Sampel.}

Sampel yang telah diambil diuji $\mathrm{pH}$ nya, lalu sampel langsung dibawa ke laboratorium. Sampel lalu diawetkan dengan perlakuan: a). Sampel untuk analisa logam berat diawetkan dengan penambahan $\mathrm{HNO} 3$ p.a sampai $\mathrm{pH} \leq 2$. Kemudian botol dibungkus dengan aluminium 
foil dan dimasukkan ke dalam lemari pendingin b). Sampel untuk analisa nitrat diawetkan dengan penambahan $\mathrm{H}_{2} \mathrm{SO}_{4}$ p.a sampai $\mathrm{pH} \leq 2$. Kemudian dibungkus dengan aluminium foil dan dimasukkan ke dalam lemari pendingin.

\section{Metode Analisa.}

Untuk pembuatan kurva standar, larutan standar Fe 100 ppm yang dibuat diambil dari larutan induk Fe 1000 ppm. Larutan ini diencerkan dengan konsentrasi 0,$2 ; 0,4 ; 0,8 ; 2,0$; dan 4,0 ppm sebagai larutan standar. Kemudian diukur dengan AAS pada panjang gelombang $248,3(\mathrm{Fe}) \mathrm{nm}$ dan $324,8 \mathrm{~nm}(\mathrm{Cu})$.

\section{HASIL DAN PEMBAHASAN}

Penentuan Parameter Fisika.

Hasil analisa parameter fisika dari 3 tempat depot air minum isi ulang di Pekanbaru dapat dilihat pada tabel 1 dan 2 .

Tabel 1. Hasil pengukuran parameter fisika untuk air baku

\begin{tabular}{|l|l|l|l|l|l|}
\hline $\begin{array}{c}\text { Kode } \\
\text { Sampel }\end{array}$ & $\begin{array}{c}\text { Suhu } \\
\text { Udara } \\
\left({ }^{\circ} \mathrm{C}\right)\end{array}$ & $\begin{array}{c}\text { Suhu } \\
\text { Air } \\
\left({ }^{\circ} \mathrm{C}\right)\end{array}$ & Warna & Rasa & Bau \\
\hline ABG & 30 & 32 & $\begin{array}{l}\text { Tidak } \\
\text { berwarna }\end{array}$ & Asam & $\begin{array}{l}\text { Tidak } \\
\text { berbau }\end{array}$ \\
\hline ABT & 29 & 30 & $\begin{array}{l}\text { Tidak } \\
\text { berwarna }\end{array}$ & Asam & $\begin{array}{l}\text { Tidak } \\
\text { berbau }\end{array}$ \\
\hline ABP & 32 & 31 & $\begin{array}{l}\text { Tidak } \\
\text { berwarna }\end{array}$ & Asam & Berbau \\
\hline NAB* & - & $\begin{array}{l}\text { Suhu } \\
\text { Udara } \\
\pm 3^{\circ} \mathrm{C}\end{array}$ & $\begin{array}{l}\text { Tidak } \\
\text { berwarna }\end{array}$ & $\begin{array}{l}\text { Tidak } \\
\text { berasa }\end{array}$ & Tidak \\
berbau
\end{tabular}

ABG (Air baku daerah Gobah), ABT (Air baku daerah Tangkerang), ABP (Air baku daerah Panam) *permenkes

Tabel 2. Hasil Pengukuran Parameter Fisika untuk Air Minum Isi Ulang

\begin{tabular}{|l|l|l|l|l|l|}
\hline $\begin{array}{c}\text { Kode } \\
\text { Sampel }\end{array}$ & $\begin{array}{c}\text { Suhu } \\
\text { Udara } \\
\left({ }^{\circ} \mathbf{C}\right)\end{array}$ & $\begin{array}{c}\text { Suhu } \\
\text { Air } \\
\left({ }^{\circ} \mathbf{C}\right)\end{array}$ & Warna & Rasa & Bau \\
\hline AMG & 30 & 33 & $\begin{array}{l}\text { Tidak } \\
\text { berwarna }\end{array}$ & $\begin{array}{l}\text { Tidak } \\
\text { berasa }\end{array}$ & $\begin{array}{l}\text { Tidak } \\
\text { berbau }\end{array}$ \\
\hline AMT & 29 & 31 & $\begin{array}{l}\text { Tidak } \\
\text { berwarna }\end{array}$ & $\begin{array}{l}\text { Tidak } \\
\text { berasa }\end{array}$ & $\begin{array}{l}\text { Tidak } \\
\text { berbau }\end{array}$ \\
\hline AMP & 32 & 31 & $\begin{array}{l}\text { Tidak } \\
\text { berwarna }\end{array}$ & $\begin{array}{l}\text { Tidak } \\
\text { berasa }\end{array}$ & $\begin{array}{l}\text { Tidak } \\
\text { berbau }\end{array}$ \\
\hline NAB & - & Suhu & Tidak & Tidak & Tidak \\
\hline
\end{tabular}

\begin{tabular}{|c|c|c|c|}
\hline Udara & berwarn & berasa & ber \\
\hline
\end{tabular}

AMG (Air minum daerah Gobah), AMT (Air minum daerah Tangkerang), AMP (Air minum daerah Panam)

Table 1 dan 2 memperlihatkan perbandingan parameter fisika dari air baku dan air isi ulang pada depot air minum di tiga lokasi kota Pekanbaru yaitu Gobah, Tangkerang dan Panam. Berdasarkan table 1, parameter fisika untuk suhu berkisar dari suhu 30 hingga $32^{\circ} \mathrm{C}$ dan air terlihat jernih (tidak berwarna) pada ketiga lokasi. Sedangkan untuk rasa ternyata air baku di tiga lokasi tersebut memiliki rasa asam dan air baku di daerah Panam berbau. Melihat kondisi daerah Pekanbaru yang banyak memiliki tanah rawa merupakan salah satu penyebab rasa air menjadi asam karena kandungan asam humitnya. Rasa juga dapat muncul secara alamiah akibat proses biologi, dan juga karena kontaminasi oleh bahan kimia atau hasil samping pengolahan air [9]. Setelah air baku diolah di depot air minum, hasil pengukuran parameter fisika yang dilakukan untuk air minum isi ulang terhadap tiga tempat depot air minum menunjukkan suhu air minum tertinggi yaitu pada sampel AMG $\left(33^{\circ} \mathrm{C}\right)$, tetapi masih dalam ketentuan yang ditetapkan (suhu udara $\pm 3^{\circ} \mathrm{C}$ ). Dari segi warna, sampel air minum (AMG, AMT, dan AMP) telah memenuhi standar yang telah ditetapkan yaitu tidak berwarna. Begitupun penentuan rasa untuk air minumnya yaitu tidak berasa. Hal ini jelas telah memenuhi standar baku mutu air minum yang telah ditetapkan oleh [10] untuk suhu, warna, rasa dan bau.

\section{Parameter Kimia.}

Hasil pengukuran parameter Kimia air baku dan isi ulang di tiga wilayah kota Pekanbaru disajikan pada tabel 3 dan 4 .

Tabel 3. Hasil Pengukuran Parameter Kimia Air Baku

\begin{tabular}{|c|c|c|c|c|c|}
\hline $\begin{array}{c}\text { Kode } \\
\text { Sampel }\end{array}$ & pH & $\begin{array}{c}\text { Besi } \\
\text { (ppm) }\end{array}$ & $\begin{array}{c}\text { Cu } \\
(\mathbf{p p m})\end{array}$ & $\begin{array}{c}\text { Nitrat } \\
\text { (ppm) }\end{array}$ & $\begin{array}{c}\text { Sulfat } \\
\text { (ppm) }\end{array}$ \\
\hline ABG & 4,21 & 0,29 & 0,300 & 9,76 & 3,00 \\
\hline ABT & 4,06 & 0,21 & 0,345 & 18,40 & 4,09 \\
\hline ABP & 4,39 & 0,19 & 0,304 & 5,78 & 2,67 \\
\hline
\end{tabular}




\begin{tabular}{|c|c|c|c|c|c|}
\hline $\mathrm{NAB}$ & $\begin{array}{c}6,5- \\
8,5\end{array}$ & 0,3 & 0,5 & 50 & 250 \\
\hline
\end{tabular}

Tabel 4. Hasil pengukuran parameter Kimia untuk air minum isi ulang

\begin{tabular}{|c|c|c|c|c|c|}
\hline $\begin{array}{c}\text { Kode } \\
\text { Sampel }\end{array}$ & pH & $\begin{array}{c}\text { Besi } \\
(\mathbf{p p m})\end{array}$ & $\begin{array}{c}\text { Cu } \\
(\mathbf{p p m})\end{array}$ & $\begin{array}{c}\text { Nitrat } \\
(\mathbf{p p m})\end{array}$ & $\begin{array}{c}\text { Sulfat } \\
(\mathbf{p p m})\end{array}$ \\
\hline AMG & 4,14 & 0,33 & 0,350 & 9,33 & 3,38 \\
\hline AMT & 3,99 & 0,25 & 0,300 & 16,18 & 4,76 \\
\hline AMP & 5,49 & 0,14 & 0,332 & 5,38 & 2,95 \\
\hline NAB & $\begin{array}{c}6,5- \\
8,5\end{array}$ & 0,3 & 0,5 & 50 & 250 \\
\hline
\end{tabular}

Hasil pengukuran $\mathrm{pH}$ pada air baku dan air minum isi ulang di tiga lokasi menunjukkan nilai 4,21dan 4,14 (Gobah); 4,06 dan 3,99 (Tangkerang); 4,39 dan 5,49 (Panam). Nilai pH ini lebih rendah dari persyaratan kualitas air minum yang telah ditetapkan oleh [10] untuk kesehatan manusia yaitu berkisar dari $\mathrm{pH}$ 6,5 8,5. Hal ini menunjukkan bahwa air baku pada tiga lokasi ini belum layak untuk dikonsumsi langsung oleh masyarakat.

Kadar logam berat. Hasil pengukuran kadar logam berat di dalam air baku terlihat di tabel 3 . Logam $\mathrm{Fe}$ dan $\mathrm{Cu}$ relatif masih rendah pada tiga lokasi dan belum melewati nilai NAB untuk syarat kualitas air minum. kadar logam $\mathrm{Fe}$ tertinggi terdapat di wilayah Gobah yaitu 0,29 ppm dan logam $\mathrm{Cu}$ tertinggi 0,345 ppm di daerah Tangkerang. Pada tabel 4 menunjukkan $\mathrm{Fe}$ dan $\mathrm{Cu}$ pada air minum isi ulang masih relatif rendah tetapi air minum isi ulang di lokasi Gobah menunjukkan konsentrasi yang melewati NAB yaitu $0,33 \mathrm{ppm}$. Tembaga berperan penting untuk pembuatan sel darah merah, pelepasan zat besi dari jaringan, pembuatan tulang dan syaraf sentral serta jaringan pengikat yang lain. Tembaga juga merupakan komponen enzim tertentu. Dengan jumlah yang berlebihan akan mengakibatkan iritasi lambung, kerusakan pembuluh darah kapiler, kerusakan jaringan hati, ginjal dan jaringan syaraf yang mengakibatkan terjadi depresi. Defisiensi $\mathrm{Cu}$ dapat menyebabkan anemia dan pertumbuhan terhambat. Gejala lainnya adalah gangguan pada tulang, kemandulan, depigmentasi pada rambut, gangguan saluran pencernaan. Pada konsentrasi rendah tembaga dibutuhkan untuk metabolism dalam tubuh [11]. Seharusnya apabila air baku yang telah mengalami proses pengolahan menjadi air minum setidaknya dapat mengurangi kadar bahan-bahan yang terlarut dalam air. Hal tersebut bisa saja terjadi karena kemungkinan pada proses pengolahan air minumnya yang menggunakan media seperti karbon aktif telah mengalami kondisi jenuh, dimana karbon aktif tersebut sudah tidak bisa lagi menyerap atau mengurangi bahanbahan yang terlarut dalam air. Di samping itu juga korosi yang terjadi di dalam alat pengolahan air minum dapat menyebabkan bertambah banyaknya konsentrasi besi di dalam air minum tersebut.

Selain logam berat juga dilakukan pengukuran terhadap kandungan nitrat dan sulfat. Kadar nitrat dan sulfat untuk air baku dan air minum isi ulang terlihat pada tabel 3 dan 4 . Hasil analisa nitrat dan sulfat pada sampel air baku menunjukkan bahwa konsentrasi nitrat tertinggi terdapat pada sampel di lokasi Tangkerang sebesar $18,40 \mathrm{ppm}$ dan 4,09 ppm. Sedangkan untuk air minum isi ulang kadar nitrat dan sulfatnya pada lokasi yang sama telah mengalami penurunan menjadi $16,18 \mathrm{ppm}$ dan 4,76 ppm dan nilai ini belum melewati NAB yang telah ditetapkan oleh [10] untuk syarat kualitas air minum. Jumlah nitrat yang besar cenderung untuk berubah menjadi nitrit di dalam usus, yang dapat bereaksi langsung dengan haemoglobin dalam darah membentuk "methaemoglobine" yang dapat menghalangi perjalanan oksigen di dalam tubuh. Sulfat terdapat secara alamiah dalam berbagai mineral dan digunakan dalam industri kimia. Sulfat dilepaskan kedalam air dari limbah industri dan melalui air hujan. Namun demikian, kadar tertinggi biasanya muncul pada air tanah dan dari sumber-sumber alam.

\section{KESIMPULAN}

Parameter fisika dari air baku dan air minum isi ulang yang terdapat pada tiga lokasi di kota Pekanbaru masih memenuhi persyaratan kualitas air yang ditetapkan oleh Menteri Kesehatan. Kadar logam berat pada air baku pada tiga lokasi di kota Pekanbaru masih memenuhi syarat kualitas air minum yang ditetapkan oleh Menteri 
Kesehatan, sedangkan pada air minum isi ulang pada satu lokasi yaitu di Gobah melebihi NAB.

\section{DAFTAR PUSTAKA}

Notoatmodjo, Soekidjo. 2003. Ilmu Kesehatan Masyarakat. Jakarta: Rineka Cipta. [1]

Slamet, Soemirat, Juli. 1995. Kesehatan Lingkungan. Jakarta: UGM Press. [2]

Aziz, Paulina. Jurnal Kajian Kualitas Air Minum Isi Ulang di Kota Pekanbaru. [3]

Akhmad, Rukaesih. 2004. Kimia Lingkungan. Jakarta: Andi Offset. [4]

Lubis, Hayati dkk. Pemeriksaan Cemaran Bakteri dan Beberapa Logam Berat pada Air Minum Isi Ulang yang Beredar di Kota Medan.17 Januari 2011. [5]

N. D. Tumin, A.L. Chuah, Z. Zawani, S.A. Rashid, Journal of Engineering Science and Technology, 3/2 (2008) 180. [6]

A. Kapoor, T. Vararaghavan, D.R. Cullimore, Bioresource Technology 70 (1999) 95. [7]

D.S. Kim, Bioresource Technology 87 (2003) 35 [http:/www. sciencedirect.com]. [8]

Direktorat Penyehatan Air. 1996. Dasar Penetapan Dampak Kualitas Air terhadap kesehatan Masyarakat. Departemen Kesehatan: Bakti husada. [9]

Persyaratan Kualitas Air Minum, Peraturan Menteri Kesehatan No. 492/MENKES/IV/2010. [10]

Darmono. 2001. Lingkungan Hidup dan Pencemaran: Hubungannya dengan Toksikologi Senyawa Logam. Jakarta: UI Press. [11] 